\title{
Overview of the market and consumption of pulses in Europe
}

\author{
Anne V. C. Schneider* \\ AEP, European Association for Grain Legume Research, Executive Secretariat, 12 Avenue George V, 75008 Paris, France
}

\begin{abstract}
The human consumption of grain legumes and pulses in Europe and the EU is lower than in other regions of the world. However, there is a lot of variation between countries and an overall slight increase has been observed in recent years. The major trends in the EU pulse market are illustrated here with a specific focus on Spain, France and the UK, which account for about $60 \%$ of the EU pulse consumption. The ways in which pulses are consumed are very different in the various EU countries, due to different regional food habits and traditions, and to differences in the supplies of grain legumes and the markets. Canned products dominate pulse sales compared with dry pulses sold in packets. Dry beans are the most consumed of the pulses in the $\mathrm{EU}$, but the preference between species varies according to country. The factors limiting the consumption of pulses in the EU are mainly: an inadequate level of innovation for developing products adapted to modern life, a small home supply of pulses and competition from cheaper low-quality imports. Recently, however, consumers are favouring healthy and balanced vegetable diets. Pulses have significant nutritional and health advantages for consumers and their cultivation has a positive impact on agriculture and the environment. Therefore the trend in the consumption of pulses could change, especially if publicity about the benefits of pulses is improved and if the food industry and professional organizations take up the challenge to incorporate grain legumes in novel, convenient and healthy food products.
\end{abstract}

Grain legumes: Pulses: Human consumption: Market: European Union: Consumer

\section{Introduction}

Grain legumes are plants belonging to the Leguminosae family. A large range of species of grain legumes is cultivated throughout the world, primarily for their grains, which are harvested at maturity and marketed as dry products, usually called pulses by industry and the trade. These products are rich in protein and usually also rich in starch. This term 'pulses' excludes the 'leguminous oilseeds', such as soyabeans, which are primarily processed for oil extraction.

The world production of pulses was 53.6 million tonnes (Mt) in 2001/2002 (Fig. 1; AEP, 2002). For comparison, in
$2001 / 2002$, the world production of soyabeans was $184 \mathrm{Mt}$ (with $43 \%$ being produced by the USA) and the world production of wheat was $583 \mathrm{Mt}(41 \%$ from Asia and $34 \%$ from Europe).

With respect to pulses, Canada and the EU are the main pea-producing countries and the Indian subcontinent and South America are the main regions producing dry beans (Phaseolus spp. and Vigna spp.; Fig. 1). The main region consuming pulses is the Indian subcontinent. In 1999, the food supply of pulses in Asia and India represented $56 \%$ and $36 \%$ of the world food supply of pulses, respectively. Africa and the Americas use $18 \%$ and $20 \%$ of the world supply, respectively,

Abbreviations: AEP, Association Européenne de Recherche sur les Protéagineux, European Association for Grain Legume Research; AND, Agriculture Nutrition Développement (Paris, France) (this is an advisory company); APPO, Association pour la Promotion des Protéagineux et Oléagineux (Gembloux, Belgium); BSE, bovine spongiform encephalopathy; FAO, Food and Agriculture Organization (of the United Nations); FNLS, Fédération Nationale de Légumes Secs (Paris, France); LINK, Legume Interactive Network; Mt, million tonnes; ONIOL, Office National Interprofessionnel des Oléagineux, Protéagineux et Cultures Textiles (Paris, France); PGRO, Processors and Growers Research Organization (Peterborough, UK); UNIP, Union Nationale des Plantes Riches en Protéines (Paris, France).

Note: LINK (Legume Interactive Network) is a thematic network supported by the FAIR programme of the European Union (CT98-3923) and co-ordinated by AEP (the European Association for Grain Legume Research). The LINK food survey, carried out by C. Kokkolis between September 1999 and March 2000, was directed by the University of Reading and PGRO (Processors and Growers Research Organization) and involved interviews of French, Spanish and British industrialists and researchers and a bibliographic study. Source for Europe: AEP and UNIP (Union Nationale des Plantes Riches en Protéines) (France), Maviga (UK). Source for France: FNLS (Fédération Nationale des Légumes Secs), UNILET (Union Nationale Interprofessionnelle des Légumes Transformés), William Saurin, CIACAM (Comptoir Agricole du Commerce Algéro-malgache), Auchan. Information for Spain: mainly from Mercadona \& Alimentos naturales.

* Corresponding author: Anne V. C. Schneider, tel +33 14069 4909, fax +33 14723 5872, email a.schneider-aep@prolea.com 


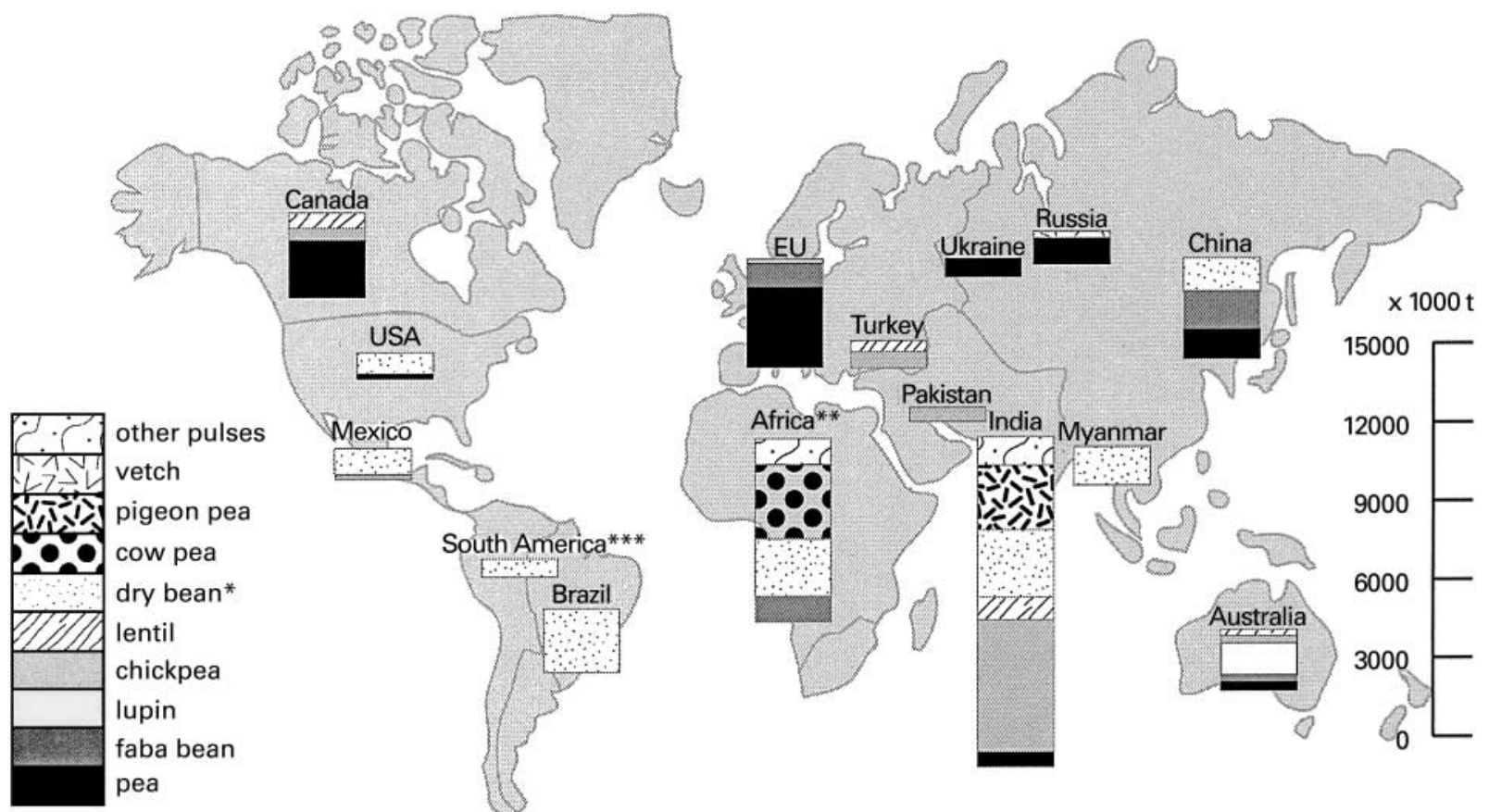

Fig. 1. Main countries producing major grain legumes (excluding soyabeans) in 2001/2002 (harvest of mid 2001 for the northern hemisphere and harvest of early 2002 for the southern hemisphere). E Other pulses; vetch; 泟 pigeon pea; cow pea; $\square$ dry bean (Phaseolus spp. and Vigna spp. without cow pea species); lentil; $\square$ chickpea; $\square$ lupin; $\square$ faba bean; $\square$ pea. ${ }^{* *}$ Faba bean, exclusively in North Africa (mainly Egypt); ${ }^{* \star *}$ except Brazil. Total production: 53.6 Mt. (AEP, 2002.)

and the consumption of food pulses per capita in these countries is large (Table 1).

The present paper focuses on Europe and, more precisely, the European Union (with 15 Member States: EU-15). This is a major producing region but with low consumption compared with other continents. In 1999 the EU used only $4 \%$ of the world supply of food pulses and the estimate of its annual consumption of food pulses ('food supply of pulses' as defined by the Food and Agriculture Oganization, FAO) was $3.9 \mathrm{~kg} / \mathrm{capita}$ (Table 1). The major pulses grown in the EU-15 are peas (Pisum sativum), faba beans (Vicia faba), vetches (Vicia sativa), dry beans (mainly Phaseolus spp.), chickpeas (Cicer arietinum), lupins (Lupinus spp.) and lentils (Lens culinaris). In this region, grain legumes were developed in the $1980 \mathrm{~s}$ to provide the compound feed industry with

Table 1. World food supply in volumes (t) and per individual ( $\mathrm{kg} /$ capita per year) of pulses (Food and Agriculture Organization, 2001)

\begin{tabular}{|c|c|c|c|c|}
\hline & \multicolumn{2}{|c|}{$\begin{array}{l}\text { Volume of the annual } \\
\text { consumption of food } \\
\text { pulses }(t)\end{array}$} & \multirow{2}{*}{$\begin{array}{c}\text { Percentage of } \\
\text { world food } \\
\text { supply used in } 1999\end{array}$} & \multirow{2}{*}{$\begin{array}{l}\text { Annual consumption } \\
\text { per individual in } 1999 \\
\text { (kg/capita per year) }\end{array}$} \\
\hline & 1989 & 1999 & & \\
\hline World & 32224582 & 35429897 & $100 \cdot 0$ & 5.9 \\
\hline \multicolumn{5}{|l|}{ Main continents } \\
\hline Asia & 20044432 & 20043900 & $56 \cdot 6$ & $5 \cdot 6$ \\
\hline Africa & 5016116 & 6268200 & $17 \cdot 7$ & $8 \cdot 1$ \\
\hline S. America & 2698899 & 3491334 & $9 \cdot 9$ & $10 \cdot 3$ \\
\hline N. and Central America & 2257861 & 3425711 & $9 \cdot 7$ & $7 \cdot 2$ \\
\hline Europe & 1558198 & 2001979 & $5 \cdot 7$ & $2 \cdot 8$ \\
\hline EU-15 & 1057657 & 1473197 & $4 \cdot 2$ & 3.9 \\
\hline Oceania & 99193 & 198774 & 0.6 & $6 \cdot 8$ \\
\hline \multicolumn{5}{|c|}{ Selected consuming countries from each continent (ordered by $\mathrm{t}$ ) } \\
\hline India & 11891395 & 12712596 & $35 \cdot 9$ & $12 \cdot 8$ \\
\hline Brazil & 2125490 & 2705280 & $7 \cdot 6$ & $16 \cdot 1$ \\
\hline UK & 196613 & 395001 & $1 \cdot 1$ & $6 \cdot 6$ \\
\hline Burundi & 244446 & 254871 & 0.7 & $40 \cdot 7$ \\
\hline Australia & 81327 & 172350 & 0.5 & $9 \cdot 1$ \\
\hline Yugoslavia (former) & - & 133878 & 0.4 & $7 \cdot 8$ \\
\hline Nicaragua & 61937 & 124104 & 0.4 & $25 \cdot 1$ \\
\hline Lebanon & 33252 & 50299 & 0.1 & $14 \cdot 6$ \\
\hline
\end{tabular}


a source of home-produced protein, and peas have been the most successful species in terms of home production. With the exception of peas, there is a deficit in EU production of all the grain legumes consumed by humans, especially Phaseolus beans, lentils and chickpeas.

The present paper describes some of the main trends in EU pulse consumption and marketing, as a background for the scientific articles contained in the present British Journal of Nutrition supplement.

\section{Methods of investigation and data}

It is extremely difficult to assemble global and national economic data which represent accurately the real situation for pulses and grain legumes, because:

(1) there are not many organizations that deal specifically with the production and marketing of grain legumes on a worldwide basis; and

(2) the nomenclature of grain legumes may vary between the scientific community and industry and from one country to another; trade classes may also be different from one continent to another.

The LINK 'Human Food' survey (Kokkolis, 2000) enabled market trends and the opinions of industrialists in Europe to be investigated and documented, in order to identify the constraints and advantages of pulses for human nutrition. Following a literature review to assess critical issues regarding food uses, this survey consisted of an initial set of interviews (with a reference questionnaire) with selected individuals from the scientific and industrial sectors related to the food chain of the European legume market. With limited time and resources available, it was most cost-effective to visit selected individuals in the UK, Spain and France, since it is estimated that these countries account for about $60 \%$ of the total annual EU pulse consumption in terms of volume. Information from these interviews highlighted the situation based on the opinions of players in this food chain in the countries investigated and at a specific date. Most of the time, those being interviewed provided estimates based on experience, but these were usually close to the exact quantitative picture and were adjusted in the light of the following official statistic sources: FAO, national professional organizations, the Spanish Ministry of Agriculture, the LINK investigation, the CICILS/IPTIC Conference, Stat Publishing, Abare and Association Européenne de Recherche sur les Protéagineux (AEP).

The data and analyses for France, in particular, are complemented by data from a national survey on peas, lentils, chickpeas and Phaseolus beans which includes market analyses and covers the years 1997-9 (UNIP-ONIOL, 2000).

\section{Overall consumption and regional habits}

It is assessed that the EU-15 used about $6.5 \mathrm{Mt}$ of pulses in 1999-2000, both for feed and for food outlets, with 5.2 Mt from home production and $1.9 \mathrm{Mt}$ from imports (F. Muel and J.-P. Lacampagne, personal communication). Domestic consumption of food pulses in the EU was estimated to be $1.18 \mathrm{Mt}$ (i.e. only $18 \%$ of the total EU use of pulses) in $1999-2000,41 \%$ of which were dry beans $(480000 \mathrm{t})$, $21 \%$ dry peas $(250000 \mathrm{t}), 14 \%$ lentils $(165000 \mathrm{t}), 13 \%$ faba beans $(150000 \mathrm{t})$ and $11 \%$ chickpeas $(135000 \mathrm{t})$.

The annual food supply per capita (i.e. the suspected consumption per capita per year) of pulses is $2.8 \mathrm{~kg}$ in Europe and $3.9 \mathrm{~kg}$ in the EU-15, whereas it is $5.9 \mathrm{~kg}$ / capita for the world and $40.7 \mathrm{~kg} /$ capita in Burundi (Table 1).

There has been a slight overall increase in the food supply of pulses available for consumption within the EU, but the trends are very different from one country to another, as are the traditional habits in terms of the type of pulses consumed (Food and Agriculture Organization, 2001) (Table 2). In 1999, the UK was the largest EU consumer of pulses, followed by countries in the south of

Table 2. Food supply of pulses in 1999 in the European Union according to Food and Agriculture Organization data (2001)

\begin{tabular}{lrrrr}
\hline & Beans $(\mathrm{t})$ & Peas $(\mathrm{t})$ & Other pulses $(\mathrm{t})$ & Total pulses $(\mathrm{t})$ \\
\hline European Union (15) & 376659 & 657920 & 435618 & 1473197 \\
Austria & 3045 & 4053 & 635 & 7732 \\
Belgium-Luxembourg & 10457 & 13000 & 2018 & 25475 \\
Denmark & 676 & 4000 & 673 & 5349 \\
Finland & 79 & 6200 & 79 & 6358 \\
France & 56075 & $45712^{*}$ & 31688 & 133476 \\
Germany & 10000 & $118446^{*}$ & 37500 & 165946 \\
Greece & 33347 & 140 & 18711 & 52198 \\
Ireland & 1589 & 5470 & 266 & 7325 \\
Italy & 90504 & 94628 & 160184 & 345316 \\
Netherlands & 10000 & 29000 & 7300 & 46300 \\
Portugal & 32092 & 3347 & 8192 & 43631 \\
Spain & 69872 & 2966 & 153945 & 226783 \\
Sweden & 1923 & 10000 & 384 & 12307 \\
United Kingdom & 60000 & $320958^{*}$ & 14043 & 395001 \\
\hline
\end{tabular}

*AEP note: In the Food and Agriculture Organization (FAO) data, the total volume of peas supplied for human consumption in France is overestimated (compare the amount of $6000 \mathrm{t}$ from a national professional source; Table 3). This is also true for the UK (61000t cited by professional sources) and seems also to be so for Germany. Some amounts of peas used in the animal industry might be included in some sources of data used by FAO. 
Europe: Italy, Spain, Greece and Portugal. While the UK and Italy have shown an increasing trend in the past 10 years (although the erratic UK trend from one year to another makes the FAO data look erroneous), the other traditional major consumers, especially Greece and Portugal, show a decreasing trend during the same period of time. In the remaining countries of the EU, consumption is below the EU average and has been relatively stable over the past 10 years, with the exception of Ireland which has shown a strong decrease per capita, and Germany which nearly doubled its consumption, albeit to only $2 \mathrm{~kg} /$ capita per year. In addition, a very small but regular increase has been observed in France. Scandinavian countries are the lowest consumers of pulses.

Dry beans are the most consumed of the pulses in the EU, but the data are not really clear because the different species are known by different names in different countries and according to their use. Phaseolus and Vigna spp. are sometimes considered together, as for customs data; faba beans (also called broad beans) are sometimes called simply 'beans' by native English speakers; and there are some unclear boundaries between the dry and fresh bean markets.

Dry common beans (Phaseolus spp.) represent at least one-third of EU pulse consumption. Their consumption in the EU was estimated at 345000t in the 1999-2000 season by Union Nationale des Plantes Riches en Protéines (UNIP), $280000 \mathrm{t}$ according to a UK private company; and $372300 \mathrm{t}$ according to FAO. They represent about onethird of the total Spanish pulse market, nearly $85 \%$ of the UK pulse market, and nearly half of the French consumption of pulses. White Phaseolus beans account for nearly $80 \%$ of Phaseolus consumption.

The EU production of Phaseolus beans was about $115000 \mathrm{t}$ in 1999 (Food and Agriculture Organization, 2001) and was mostly in southern Europe. Imports to the EU reached $410000 \mathrm{t}$ in 1999 (UNIP, 2001), a level that has been relatively stable for 5 years. The UK, Italy, Spain and France are the main importers; Canada and the USA are the main exporters to the EU (Schneider \& Lacampagne, 1999).

\section{The French situation}

In France, home production of the different food pulses contributes less than $20000 \mathrm{t}$ to the national supply. France is the largest pea-producer in the EU: most of this production is for the animal feed industry and the food pea market is self-sufficient. Lentils, beans and chickpeas are produced locally on a small scale and the market is based largely on imports. Home production amounts to about $20 \%, 8 \%$ and $2 \%$ of consumption for lentils, beans and chickpeas, respectively. The development of products with a guaranteed origin and with high added value for home production has been successful for French niche markets, the key example being the green lentils 'Lentille verte du Puy'.

The imports (estimated at $80000 \mathrm{t} /$ year) represent $80 \%$ of the French market of food pulses, $90 \%$ of the supply for industry and $75 \%$ of the supply for the grocery stand sector. The business is specialized, with a few traders
Table 3. Human consumption of pulses in France in 1988; source: AEP extraction issued from Agriculture Nutrition Développement (AND) (UNIP-ONIOL, 2000)

\begin{tabular}{lcc}
\hline & Consumption $(\mathrm{t})^{\star}$ & $(\%)$ \\
\hline Types of uses & & \\
$\quad$ Grocery stand & 25700 & $26 \cdot 8$ \\
Processed products & 50100 & $52 \cdot 3$ \\
Restaurants, canteens, etc. & 20000 & $20 \cdot 9$ \\
$\quad$ Total & 95800 & 100 \\
Pulse species & & \\
Phaseolus beans & 44725 & $46 \cdot 7$ \\
Lentils & 27625 & $28 \cdot 8$ \\
Chickpeas & 9400 & $9 \cdot 8$ \\
Peas ('pois cassés') & 6000 & $6 \cdot 3$ \\
Others & 8050 & $8 \cdot 4$ \\
Total & 95800 & 100 \\
\hline
\end{tabular}

* Dry seed equivalents (based on assessments from the quantities of endproducts sold after processing).

and large direct imports by some big industrialists. This market is highly concentrated: three canneries and two packaging companies have $70 \%$ of the market share, leaving the rest to fifty local businesses with small volumes.

In 1997 and 1998 the food pulses market in France was investigated in a professional study involving panels of consumers (UNIP-ONIOL, 2000). In 1998 the human consumption of pulses was about $95800 \mathrm{t}$ dry seed equivalents, $50 \%$ of which were beans and $29 \%$ were lentils (Table 3 ). There are three main market sectors for pulses: pulses sold on grocery stands (uncooked dry seeds in packets), tins containing pulses alone and tins containing cooked food dishes with pulses added. More than half of the raw food pulses are processed and bought by households in tins (Table 4). The canned pulses sector is dynamic with stable prices and it concerns $52 \%$ of the purchasing households, with a level of purchase of $2.5 \mathrm{~kg} /$ household per year. The canned cooked dishes sector concerns $57.6 \%$ of the purchasing households, with a level of purchase of $4.7 \mathrm{~kg} /$ household per year and with increasing prices; and it is dominated by cassoulet (a French dish cooked with white beans). Grocery stands, selling uncooked dry seeds in packets, are dominated by lentils; this sector covers $40 \%$ of purchasing households and has stable prices and levels of purchase reaching $1.5 \mathrm{~kg} /$ household per year. It was quite stable (+1\%) between 1997 and 1998, with good elasticity of purchases versus price trends for each product.

The French outlets are fragmented: there is no connection between the fresh market and dry products, species can not substitute for each other and one can observe regional variations in food pulse consumption habits. The medium and large retailers dominate the three market sectors: $45-47 \%$ of the total volume for hypermarkets, $35-40 \%$ for supermarkets and $8-20 \%$ for hard discount (the market share of which increased from $12 \%$ to $19 \%$ in volume and from $6 \%$ to $12 \%$ in value between 1997 and 1998).

For the three sectors, the consumer profile varies according to each type of pulse, end-products and regions. People in the 35- to 49-year-old age group were the most frequent purchasers and bought the most pulses. These were followed by the 50 - to 64 -year-old age group for the uncooked 
Table 4. Market sectors for pulses in France in 1988; source: AEP compilation from AND (UNIP-ONIOL, 2000)

\begin{tabular}{|c|c|c|c|}
\hline Product & Volume (t) & Market volume (\%) & Market value (\%) \\
\hline \multicolumn{4}{|l|}{ Grocery stand } \\
\hline Packets of lentils & 10800 & 76 & 72 \\
\hline Packets of white beans & 2200 & 15 & 17 \\
\hline Packets of chickpeas & 760 & $5 \cdot 3$ & 5 \\
\hline Packets of red beans & 490 & 3.6 & 4 \\
\hline Total grocery stand & 14250 & & 12 \\
\hline \multicolumn{4}{|l|}{ Canned pulses alone } \\
\hline Tins of white beans & 12900 & 42 & 39 \\
\hline Tins of lentils & 8500 & 28 & 30 \\
\hline Tins of chickpeas & 6000 & 20 & $18 \cdot 5$ \\
\hline Tins of red beans & 3000 & 10 & 14 \\
\hline Total canned pulses alone & 30400 & & 22 \\
\hline \multicolumn{4}{|l|}{ Canned cooked food with pulses } \\
\hline Tins of 'cassoulet' & 41000 & 64.5 & 65 \\
\hline Tins of dishes cooked with lentils & 17000 & 27 & 24 \\
\hline Tins of 'chilli con carne' & 3000 & 12 & 13 \\
\hline Tins of other French dishes & 2300 & $3 \cdot 8$ & $5 \cdot 8$ \\
\hline Total canned cooked food with pulses & 63300 & & 67 \\
\hline
\end{tabular}

dry pulses and canned pulses, and by the below 35-year-old age group for the cooked canned pulse dishes. The consumption of pulses is higher among the lower socio-economic groups of the population, increases with increased size of the household (households with four or more persons) and increases in rural areas (with the exception of canned cooked pulses).

The perception of pulses by consumers, analysed qualitatively in this French survey, is characterized by a series of paradoxes and contradictions. The origin of pulses is associated clearly with authenticity, but their place on the supermarket shelves changes frequently and is not always clearly marked; the lack of 'sell-by' dates or product information also leaves purchasers lacking confidence in the product. In addition, the perception varies according to the retailing method and display on market stands. Consumers have contradictory subjective feelings: they may consider pulses as products beneficial for a balanced diet and with nutritional value, but also as a source of flatulence or likely to increase body weight; they can have a positive exotic and mythical image, but also an old-fashioned and military image. Consumers are interested in more readyto-cook products which are easy to use; a move from grocery stand to supermarket shelf. Lentils are especially appreciated because they can be cooked more rapidly and they offer lots of possibilities for cooking a range of dishes.

\section{The UK situation}

The UK demand for peas for human consumption was assessed by the British Edible Pulse Association (BEPA) and the Processors and Growers Research Organization (PGRO) to be about 61000 t in 1999: $45000 \mathrm{t}$ of canning or processed marrowfats, $12000 \mathrm{t}$ of packets of marrowfats and $4000 \mathrm{t}$ of canning 'small blues'.

According to interviews with industrialists (Kokkolis, 2000), the pea market in the UK is a self-sufficient market with a stable or declining trend. It is dominated by marrowfat peas, but there is still a diversity of pea varieties and food products:

- packets of dry seeds ('marrowfats', split peas, whole green peas);

- tinned peas, which are the main outlet (mainly 'marrowfats' and 'English blue' peas, a small number of split peas and some 'whole green peas'); in contrast with other countries, where it is forbidden, the UK industry uses colour additives for canned peas;

- mushy peas (decorticated 'marrowfat' peas);

- processed peas (previously imported 'Alaska' peas but recently substituted for 'English blue' peas);

- catering industry (fish and chip shops, school meals);

- dry-mixed products (including other vegetables), such as soups;

- flours (mainly for the ethnic market).

In contrast with peas, the common bean (Phaseolus beans) market is a buoyant market. Like peas, most of the sales are canned, especially canned baked beans, and there are six times as many canned beans as canned peas. During the Second World War, large quantities of baked beans were consumed by British troops and, to supply its large canning factory, Heinz needed regular large-scale deliveries of high-quality, low-price beans. Since small-scale UK bean suppliers could not meet the need, $80000-100000 \mathrm{t}$ of navy beans were imported from the USA. Since then, the main UK bean processors have been importing massive quantities of beans, mainly from the USA, but also from Canada and China to a lesser extent, due to lower prices.

Today there are some attempts to develop UK varieties with superior quality to compete with imports. Only small areas (approximately 110 ha/year) have been grown for the past few years, due to the lack of EU aid-schemes (in contrast with 80000 ha of faba beans). The dry bean imports (nearly the sole source of beans in the UK) represented $126000 \mathrm{t}$ in 1999 (Phaseolus and Vigna spp.) (123000 t from outside the EU) (Eurostat statistics).

UK products which include Phaseolus beans are: 
- fresh or uncooked forms (either fresh pods or packeted dry beans; fresh beans are marketed whole, those for canning or freezing are sliced);

- germinated beans (mostly Middle East/Africa/Asia);

- frozen cooked packs;

- canned/glass-bottled cooked beans (baked bean consumption has been estimated at $100000 \mathrm{t} /$ year in the UK) both for 'conventional' and vegetarian recipes;

- chilled form (developing in the food service industry);

- American salad bars, especially with red kidney beans.

Bean flours and powders are also being tested experimentally as food ingredients.

Chickpeas, faba beans and lentils represent small UK markets which are targeted at minority and ethnic niche markets (African or Asian immigrants and a small proportion of South European consumers). They are sold mainly as dry seeds in packets, although there is a slight increase in tins of lentils and chickpeas. Nearly all the domestic faba bean production is exported to Middle Eastern and African countries.

\section{The Spanish situation}

Consumption of pulses is traditional in Spain and they feature prominently in the Mediterranean diet. Consumption used to be higher in the past but national data have been available only since 1987 . The major change has been the strong decrease in domestic production since the $1980 \mathrm{~s}$, accompanied by increased imports (Muzquiz, 1997).

Today, Spain imports about $70 \%$ of its food pulses. In 1999, $163000 \mathrm{t}$ of beans, lentils and chickpeas were imported (UNIP, 2001), whereas the domestic production of these three species amounted to $68200 \mathrm{t}$ (Spanish Ministry of Agriculture, 2001). Of Phaseolus bean imports, $59 \%$ are from Argentina (mainly alubias); $84 \%$ of chickpea imports are from Mexico; and $98 \%$ of lentil imports are from North America, $54 \%$ from the USA and $44 \%$ from Canada (UNIP, 2001).

As with other European countries, this large share of imports is due to the relatively small agricultural systems compared with those of Argentina, USA or Canada, combined with the higher margins demanded by farmers and lower support for these crops (EU Common Agricultural
Policy regulatory system). The cost of legumes per unit weight sold to the food manufacturers is therefore much higher, sometimes double that of a similar imported raw material of the same quality delivered to the port. In addition, the large local players dislike the inconsistency of the local supply, even if the home products have superior organoleptic attributes compared with imported raw materials. They regret that there are not enough home-produced pulses to satisfy their demand and to allow them to organize a stable chain.

Currently, $5 \%$ of domestic production consists of the very expensive and unique varieties (some of Protected Denomination of Origin like 'Faba Granja' from Segovia or 'Fabes' from Asturias at 18-20 euro/kg).

On average the Spanish consume 2-3 times more pulses per year than the French $(5.7 \mathrm{~kg} / \mathrm{capita}$ in 1999). Although some retailers and industrialists perceived a drop in the consumption of pulses, data from FAO and from the Spanish Ministry for Agriculture show that recently the supply volume of food pulses in Spain has been fairly stable. The total supply of beans, lentils and chickpeas remained between 210000 and $260000 \mathrm{t} /$ year and was $224000 \mathrm{t}$ in 1999. In contrast with the UK and France, the partitioning between pulse species is more balanced, with nearly onethird for beans, chickpeas and lentils, respectively, but with an increasing preference for the latter two, especially lentils (Table 5; Muzquiz, 1997). There is a very limited use of dry peas for human consumption in Spain, the animal industry being the main outlet for peas (about $60000 \mathrm{t}$ of domestic production and $500000 \mathrm{t}$ of imports). There is a small amount of local consumption of other species, such as flours of Lathyrus sativus and lupins in appetizers.

Of the total consumption of all legumes, $83 \%$ are consumed by households and $80 \%$ are packaged or processed (Table 5). According to some industrialists (Kokkolis, 2000), the proportion of pulses sold via grocery stands has decreased at a rate of $2-3 \%$ per annum, while the consumption of cooked pulses has increased at a rate of $10 \%$ per annum. This increase is found only in rural areas and is due to their healthy and natural image combined with convenience, especially after concerns raised by issues such as bovine spongiform encephalopathy (BSE) and the use of genetically modified organisms. Additionally, the tradition of pulse consumption remains strong in regions of lower

Table 5. Human consumption of pulses in Spain in 1999 (Spanish Ministry of Agriculture, 2001)

\begin{tabular}{|c|c|c|c|c|}
\hline Places of consumption & Consumption (t) & $\%$ & & \\
\hline $\begin{array}{l}\text { Home uses } \\
\text { Restaurants/hotels } \\
\text { Institutions (caterers, schools, hospitals) } \\
\text { Total }\end{array}$ & $\begin{array}{r}186000 \\
26000 \\
12000 \\
224000\end{array}$ & $\begin{array}{c}83 \cdot 0 \\
11 \cdot 6 \\
5 \cdot 4 \\
100\end{array}$ & & \\
\hline Species of pulses & & $\begin{array}{c}\text { Per capita } \\
\text { (kg/capita per year) }\end{array}$ & Bulk (t) & Packeted (t) \\
\hline $\begin{array}{l}\text { Beans } \\
\text { Chickpeas } \\
\text { Lentils } \\
\text { Total legumes }\end{array}$ & $\begin{array}{r}58000 \\
78000 \\
88000 \\
224000\end{array}$ & $\begin{array}{l}1.4 \\
1.9 \\
2 \cdot 2 \\
5 \cdot 6\end{array}$ & $\begin{array}{l}14000 \\
16000 \\
12000 \\
42000\end{array}$ & $\begin{array}{r}43000 \\
61000 \\
76000 \\
180000\end{array}$ \\
\hline
\end{tabular}


income (usually rural areas), while consumption has decreased in urban areas (higher socio-economic groups).

The most popular use of pulses in Spain is for the traditional home-made meals, particularly fabada (made with pork and very large white beans of high quality and high price, grown only in Spain), and cocido (made with chickpeas, Spanish sausages (chorizo) and meat). The latter dish accounts for $65 \%$ of the chickpeas consumed. To prepare fabada, the food industry usually replaces Fabes (which are in limited supply) with 'normal' Alubia (Phaseolus), which are cheaper. Phaseolus beans are also used in soups, salads or eaten with rice or vegetables. Lentils are very popular, especially when eaten with sausages. There is only a very small market for dry peas, mainly as mixed snacks fried with faba beans, peanuts and chickpeas.

The Spanish pattern of pulse consumption is characterized by regional and local features: Phaseolus beans are eaten particularly in the regions of the north and in Castilla y Leon. The lowest consumption is observed in Andalucia and the Mediterranean coastal areas. The expensive varieties are more popular in the prosperous urban areas. Lentils are eaten mostly in Castilla y Leon and Castilla La Mancha, while chickpeas are eaten mostly in the poorer areas of the south, especially Andalucia, but also in Castilla y Leon. In Cataluña, Aragon and Baleares, consumption is low (Muzquiz, 1997; Kokkolis, 2000; Spanish Ministry of Agriculture, 2001)

\section{Discussion}

\section{Assets to be exploited and handicaps to be overcome}

There is scientific evidence demonstrating the nutritional value of pulses (Messina, 1999; Carnovale, 1999; Champ, 2001; Mariotti et al., 2001). Pulses are a valuable source of lysine-rich protein. They are a perfect complement for cereals in a well-balanced vegetarian diet. Pulses are a source of minerals and most of the undesirable minor components are removed or reduced by cooking. In addition, pulses have a particularly low glycaemic index, which is very interesting; and there is some evidence supporting the positive effect of eating pulses on the prevention of cardiovascular diseases and type 2 diabetes (Champ, 2001, 2002; Champ \& Muzquiz, 2001; Anderson \& Ward, 2002; Mathers, 2002).

According to consumers and industrialists, the benefits of pulses are primarily their low price and their ease of storage over a long period of time. In addition, the key words associated with pulses include 'health', 'gastronomy', 'local production' and 'authenticity', which meet several of the current trends and demands of EU consumers and EU society in general. These include increased concerns about personal health, food quality and food safety, increased interest in vegetarianism and more rustic foods that do not contain genetically modified plants, worries about animal protein sources (following the BSE epidemic), interest in exotic dishes, concerns for safer (traceable) environmentally friendly crop and food production and the increasing ethnic market (foreign immigrants in the EU).

There are some factors restricting the consumption of pulses, especially the long cooking time required by some species, the problem of flatulence, the 'oldfashioned' image and a clear lack of innovative products. Variety breeding and processing provide some opportunities to reduce $\alpha$-galactosides (the major factors involved in flatulence) but the results of research have not provided sufficient satisfactory data yet (Champ, 2001; Frokiaer et al., 2001). However, the main bottlenecks for pulse consumption are related to markets, economics and politics: a critical mass of home supply is required, together with public or private $\mathrm{R} \& \mathrm{D}$ investment, and greater marketing and publicity efforts.

\section{An opportunity market which needs to be boosted}

In the future, the initial LINK food survey should be extended to provide information about additional countries and complementary socio-economic analyses for proposing regional development strategies.

However, some major characteristics of the pulse market in the EU can be highlighted here:

1. a small volume at present compared with other food products;

2. an almost stable but fragmented market: a slightly increasing trend on average in the EU-15, with a lot of regional and local differences and with specific features for individual pulse products;

3. a concentrated and competitive market: a small number of canneries, food companies and packaging companies holds the major share of the market;

4. an inadequately low level of innovation and marketing of pulse products, victims of the vicious circle "no buoyant market - no marketing - no attractive food products';

5. a lack of consumer awareness of grain legume crops and products; and a lack of communication at many levels of the food chain (industry, retailers and consumers);

6. an inadequately small home supply which needs to be stimulated to provide a larger and more regular supply to industry;

7. a series of pulses that can offer diversity in cooking and benefits for consumers' health.

In Australia the consumption of pulses has increased dramatically over the past 20 years (half the EU consumption in 1979 and double it in 1999). Home production using Australia's large areas of arable land has certainly facilitated the development of pulse production, but the politics, agricultural context and commercial strategies have also been proactive for pulses. The situation in Australia demonstrates that consumption can change drastically and that the image 'pulses, meat of the poor' can be reversed and updated.

In the future, pulses can be re-established in European diets and the related food outlets can be increased in the EU. The strategy for initiating a real change, and a stimulus awaited by all the players of the pulse chain, from production to industry, should be based on:

(1) modern communication campaigns, in order to emphasize the nutritional and health benefits, and to modernize the image of food pulses for industry and 
consumers (well-differentiated and easily identified products, practical instructions for use and recipes);

(2) the development of modern, convenient and varied healthy products, which would stimulate demand, and encourage the food industry to invest more in these products to boost the market; a full range of high-quality products (from traditional tasty dishes to ready-to-cook products or functional ingredients) would be welcome to provide a large choice to the different types of consumers;

(3) support for research in order to reinforce the current scientific evidence on the benefits of food pulses for human nutrition and health: in addition to animal models, clinical tests should be encouraged and the benefits should be stated for the different types of consumers (ageing population, infant food, sporting population, young population);

(4) coordination of the integrated chain from the home producers to industry and consumers at the local level, for developing local politics and regional professional dynamism; this should lead to a more stable market organization (and interactions with the fresh legume sector), establish a regular supply and general confidence in pulses, publicize the local origin of pulses and grain legumes which are traceable and environment-friendly (especially because they require little or no nitrogen fertilizers).

\section{Conclusion}

Pulses meet many demands of today's society and their increased development in the EU would contribute both to environmentally friendly agriculture and to a modern and healthy food industry.

\section{Acknowledgements}

Thanks are due to Christos Kokkolis for his work on the LINK survey, to the Commission of the European Communities for its support to LINK and to UNIP-ONIOL for their permission to use results from the national study of French markets. The author would also like to thank Jean-Paul Lacampagne (UNIP) and Rosario Laguna (Servicio de Investigacion y Tecnologia Agraria) for their help in obtaining national statistics, as well as Jill Craig for editing the English.

\section{References}

AEP (2002) Statistics and economics. World production. Main grain legume producing countries in 2001. http://www. grainlegumes.com

Anderson JW \& Ward AK (2002) Pulses and lipemia: shortand long-term effects: A potential in the prevention of cardiovascular disease. British Journal of Nutrition 88, Suppl. 3, S263-S271.

Carnovale E (1999) Chickpea in the European diet. Grain Legumes 25, 14-17.

Champ MMJ (2001) Benefits of pulses in human diet. In Proceedings of the 4th European Conference on Grain Legumes, Cracow, Poland, July 2001, pp. 109-113 [AEP, editors]. Paris: AEP.

Champ MMJ (2002) Non-nutrient bioactive substances of pulses. British Journal of Nutrition 88, Suppl. 3, S307-S318.

Champ MMJ \& Muzquiz M (2001) Phaseolus beans: pros and cons for the consumer. Grain Legumes 31, 20-21.

Food and Agriculture Organization (2001) FAOSTAT Data Base. http://www.fao.org/

Frokiaer H, Barkholt V \& Bagger CL (2001) Processing: impacts on seed nutritive value - scientific, technical and economic aspects. In Proceedings of the 4th European Conference on Grain Legumes, Cracow, Poland, July 2001, pp. 127-131 [AEP, editors]. Paris: AEP.

Kokkolis C (2000) LINK Food Survey Report. Reading: University of Reading and PGRO.

Mariotti F, Tomé D \& Mahé S (2001) The nutritional value of uniformly ${ }^{15} \mathrm{~N}$ labelled pea, lupin or soy proteins assessed from real ileal digestibility and postprandial utilisation in humans. In Proceedings of the 4th European Conference on Grain Legumes, Cracow, Poland, July 2001, pp. 118-119 [AEP, editors]. Paris: AEP.

Mathers JC (2002) Pulses and carcinogenesis: potential for the prevention of colon, breast and other cancers. British Journal of Nutrition 88, Suppl. 3, S273-S279.

Messina MJ (1999) Legumes and soybeans: overview of their nutritional profiles and health effects. American Journal of Clinical Nutrition 70, 439S-450S.

Muzquiz M (1997) Spanish legumes and the Mediterranean diet. Grain Legumes 17, 22-23.

Schneider A \& Lacampagne J-P (1999) The European chickpea market: how to overcome a dependency on importers. Grain Legumes 25, 11-13.

Spanish Ministry of Agriculture (2001) In Consumption in Spain. Madrid: Sub-Secretariat of the General Direction of Food, Spanish Ministry of Agriculture, Fisheries and Food.

UNIP [Editors] (2001) Statistics - Plants rich in proteins. Paris: UNIP.

UNIP-ONIOL survey (2000) Analysis of the French market of pulses - Final report [AND, editors]. Paris: AND. 